\title{
Apple Cultivation and Breeding in Afghanistan: S-RNase Genotypes and Search System for Suitable Cultivar Combination
}

\author{
Matiullah Akbari, ${ }^{1}$ Mao Yamaguchi, ${ }^{1}$ Tsutomu Maejima, ${ }^{2}$ Shungo Otagaki, \\ Katsuhiro Shiratake, ${ }^{1}$ and Shogo Matsumoto ${ }^{1}$ \\ ${ }^{1}$ Graduate School of Bioagricultural Sciences, Nagoya University, Chikusa, Nagoya 464-8601, Japan \\ ${ }^{2}$ Nagano Fruit Tree Experiment Station, Nagano 382-0072, Japan \\ Correspondence should be addressed to Shogo Matsumoto; shogo@agr.nagoya-u.ac.jp
}

Received 21 October 2015; Accepted 30 December 2015

Academic Editor: Othmane Merah

Copyright (C) 2016 Matiullah Akbari et al. This is an open access article distributed under the Creative Commons Attribution License, which permits unrestricted use, distribution, and reproduction in any medium, provided the original work is properly cited.

\begin{abstract}
We investigated S-RNase genotypes of nine useful Afghan apple cultivars including six original cultivars and one rootstock. We also determined $S$-RNase genotypes of 11 apple cultivars and lineages and seven rootstocks in Japan. We speculated regarding the unidentified parents of cultivars and lineages from the $S$-RNase genotypes and their fruit and branch characteristics and also identified mistaken parents. We compiled a database of the apple $S$-RNase genotypes of 622 apple cultivars investigated, which included a survey system of cultivar combinations showing those that were fully incompatible, semicompatible, and fully compatible, written in the Pashto language.
\end{abstract}

\section{Introduction}

The origin of apple is in Central Asia, and many areas of Afghanistan have native apples. Apple is one of the most cultivated horticultural crops in this country since the climate is appropriate for it. The major areas of apple production, that is, areas producing more than 1,000 metric tons per year, are Ghazni, Kabul, Kandahar, Kapisa, Logar, Paktika, Paktya, Panjshir, Parwan, Uruzgan, and Wardak [1]. According to the forecast of the Ministry of Agriculture, Irrigation, and Livestock (MAIL), apple production in Afghanistan increased five to $10 \%$ from 2012 to 2013 [1]. It was 77,000 metric tons in 2013/14 (April/March) [1].

Self-incompatibility is a genetic mechanism that prevents inbreeding and promotes outcrossing in many flowering plants [2]. The gametophytic self-incompatibility (GSI) system in apple is controlled by the multiallelic $S$-locus $[2,3]$, so that when the pollen $S$-haplotype matches one of the pistil $S$ haplotypes, the pollen tube growth is arrested in the style. In apple GSI, F-box gene called SFBB (S-locus F-box brothers) and $S$-RNase gene act as pollen and pistil factors, respectively $[4,5]$. As fertilization of apple needs at least two cultivars having no or one common S-haplotype, accurate knowledge of the $S$-genotype that is identified by the $S$-RNase alleles is important for stable apple production.

Afghan apple growers know about the self-incompatibility of apple cultivars, but unfortunately they know nothing about their S-RNase allele genotypes. Currently in Afghanistan, the apple growers design their apple orchard based on the fruit skin colors of different apple cultivars. However, sometimes the combination of two apple cultivars having different skin color results in full-incompat-ibility due to their identical $S$-genotype, like $S_{2} S_{3}$ of "Jester" (red skin) and "Golden Delicious" (yellow skin). Current apple production in Afghanistan is mainly from exotic cultivars imported around 20 years ago [1]. Among various apple cultivars including "Discovery" $\left(S_{10} S_{24}\right)$ [6], "Fiesta" $\left(S_{3} S_{5}\right)$ [7], "Fuji" $\left(S_{1} S_{9}\right)[8,9]$, "Gala" $\left(S_{2} S_{5}\right)$ [7], "Golden Delicious" $\left(S_{2} S_{3}\right)$ [7], "Granny Smith" $\left(S_{3} S_{23}\right)$ [6], "Jester" $\left(S_{2} S_{3}\right)$ [10], "July Red" $\left(S_{24} S_{25}\right)$ [http://www.agr.nagoya-u.ac.jp/ hort/apple/], "Mutsu" $\left(S_{2} S_{3} S_{20}\right)$ [9, 11], "Double Red Delicious" $\left(S_{9} S_{28}\right)$ [12], "Red Devil," "Saturn," "Spartan" $\left(S_{9} S_{10}\right)$ [13], and "Summerred" $\left(S_{2} S_{9}\right.$ in Belgium, $S_{10} S_{24}$ in Japan) $[6,14]$, three cultivars "Double Red Delicious," "Golden Delicious," and "Granny Smith" (known as Green Delicious in Afghanistan) are mainly grown commercially [15]. Though the cost of 


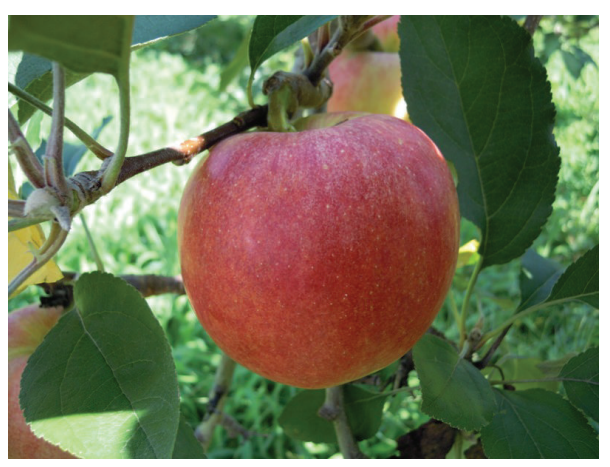

(a)

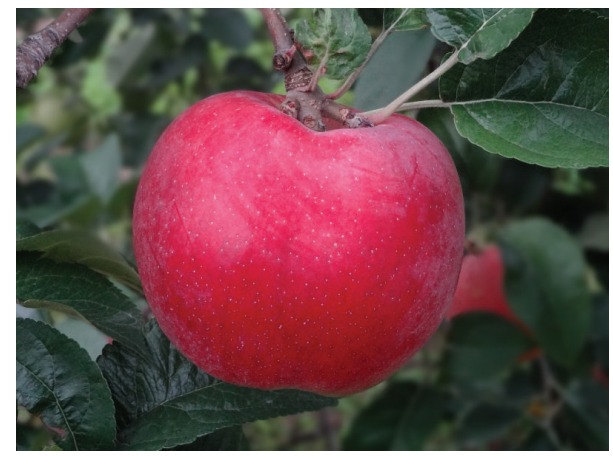

(c)

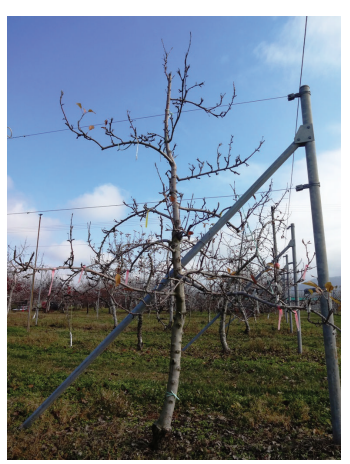

(b)

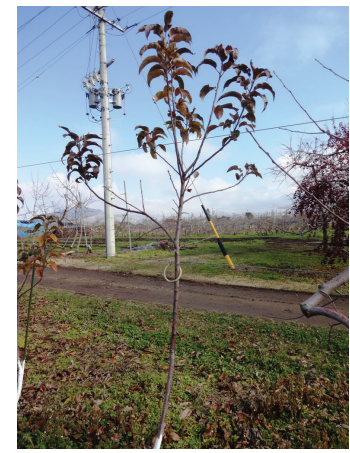

(d)

FIGURE 1: A mature fruit and a shape of tree of "Natsuotome" ((a), (b)) and "Swakko" ((c), (d)) produced at Nagano Fruit Tree Experiment Station.

apple production in Afghanistan is lower than in other countries, their apple quality is higher than the ones imported from Pakistan or Iran. Developing original new and high-quality cultivars using Afghan original cultivars seems to be important for Afghan apple growers who wish to compete in local and international markets.

In this study, we investigated the $S$-genotypes of apple cultivars and lineages including Afghan original cultivars for apple breeding and cultivation. In addition, we translated the apple $S$-RNase allele genotype database to the Pashto language and made a homepage where Afghan apple growers can search for suitable cultivar combination. Indeed, Pashto is Afghanistan's official language and is used by more than $60 \%$ of the country's populations.

\section{Materials and Methods}

2.1. Plant Material. Young leaves of six Afghan original cultivars and a rootstock, that is, "Jawrasi Golden," "Kado Seb," "Mahali" (rootstock), "Nazak Badan," "Parachinari," "Swati," "Tur Kulu," "Red Devil," and "Saturn" [15, 16], were collected from either Badam Bagh, Kabul Province, or Wardak Province in Afghanistan. Remaining apple cultivars, lineages, and rootstocks used in this study were from collections at the Iwate Agricultural Research Center, Japan, the Nagano Fruit Tree Experiment Station, Japan, or Koukaen, Esashi$\mathrm{ku}$, Oshu City, Japan. Young leaves were stored at $-80^{\circ} \mathrm{C}$ until use.

2.2. S-RNase Allele Amplification and Allele-Specific PCRRFLP Analyses. Total DNA was isolated from the leaves of individual plants [17]. The primers and conditions used for $S$-allele-specific PCR-RFLP analyses were those described by Broothaerts et al. (for $S_{2}$ and $S_{3}$ ) [18], Janssens et al. (for $S_{7}$ and $S_{9}$ ) [7], Kitahara et al. (for $S_{24}$ ) [19], Kitahara and Matsumoto (for $S_{10}$ ) [9], Matsumoto et al. (for $S_{5}$ and $S_{7}$ ) [20], Matsumoto et al. (for $S_{1}$ and $S_{20}$ ) [21], and Matsumoto and Kitahara (for $S_{28}$ ) [22].

\section{Results and Discussion}

3.1. S-RNase Genotypes of Apple Cultivars Including Afghanistan Original Cultivars. We analyzed the $S$-RNase genotypes of apple cultivars and lineages for using them in a breeding programme. S-RNase genotypes of "Iwate 4 Gou," "Natsuakari," K-20, K-21, K-22, KAD-14, KAD-17, KAD-19, KAD-20, and "Saturn" (Table 1, numbers 1, 2, 6-8, 12-15, and 25) matched one of the $S$-RNase genotypes deduced from their reputed parentage. In contrast, $S$-RNase genotypes of "Oirase," K-23, K-24, K-25, and "Red Devil" (Table 1, numbers 4,9-11, and 24) were inconsistent with the one from its reputed parents. "Natsuotome" (Table 1, number 3) was identified as $S_{7} S_{9}$, and it was suggested that "Fuji" $\left(S_{1} S_{9}\right)$ or "Alps Otome" $\left(S_{1} S_{9}\right)$ seemed to be used as a paternal parent, judging from its fruit and branch characteristics. As the average fruit weight of "Natsuotome" (195 g) is lighter than that of its maternal parent "Sansa" (280 g), its characteristics might be from "Alps Otome" (50 g), not from "Fuji" (300 g). On the other hand, the characteristics of concentrically cracking at peduncle end in "Natsuotome" are similar to "Shinano Hoppe" (Akane $\times$ Fuji), a pedigree of "Fuji" (Figure 1). "Oirase" $\left(S_{9} S_{28}\right)$ and K-24 $\left(S_{1} S_{3}\right)$ (Table 1, 
TABLE 1: S-RNase genotypes of 20 apple cultivars and 7 rootstocks including their lineage.

\begin{tabular}{|c|c|c|c|}
\hline Number & Cultivar & Reputed parentage & S-RNase genotype \\
\hline 1 & "Iwate 4 Gou" & "Fuji" $\left(S_{1} S_{9}\right) \times$ "Delicious" $\left(S_{9} S_{28}\right)$ & $S_{1} S_{28}$ \\
\hline 2 & "Natsuakari" & "Sansa" $\left(S_{5} S_{7}\right) \times$ "Yoko" $\left(S_{3} S_{9}\right)$ & $S_{3} S_{7}$ \\
\hline 3 & "Natsuotome" & Chance seedling of "Sansa" $\left(S_{5} S_{7}\right)$ & $S_{7} S_{9}$ \\
\hline 4 & "Oirase" & "Starking Delicious" $\left(S_{9} S_{28}\right) \times$ "Tsugaru" $\left(S_{3} S_{7}\right)$ & $S_{9} S_{28}$ \\
\hline 5 & "Suwakko" & "Sekaiichi" $\left(S_{3} S_{9}\right) \times$ Unknown $^{\neq}$ & $S_{3} S_{20}$ \\
\hline 6 & K-20 & "Shinano Gold" $\left(S_{1} S_{3}\right) \times$ "Beniroman" $\left(S_{3} S_{5}\right)$ & $S_{1} S_{5}$ \\
\hline 7 & $\mathrm{~K}-21$ & "Shinano Gold" $\left(S_{1} S_{3}\right) \times$ "Beniroman" $\left(S_{3} S_{5}\right)$ & $S_{1} S_{5}$ \\
\hline 8 & $\mathrm{~K}-22$ & “Orin" $\left(S_{2} S_{7}\right) \times$ "Beniroman" $\left(S_{3} S_{5}\right)$ & $S_{3} S_{7}$ \\
\hline 9 & $\mathrm{~K}-23$ & "Gunma Meigetsu" $\left(S_{1} S_{3}\right) \times$ "Shinano Gold" $\left(S_{1} S_{3}\right)$ & $S_{1} S_{x}$ \\
\hline 10 & K-24 & "Shinano Gold" $\left(S_{1} S_{3}\right) \times$ Unknown $^{+\neq}$ & $S_{1} S_{3}$ \\
\hline 11 & $\mathrm{~K}-25$ & "Shinano Gold"+ $\left(S_{1} S_{3}\right) \times$ "Fuji" $\left(S_{1} S_{9}\right)$ & $S_{9} S_{x}{ }^{\Im}$ \\
\hline 12 & KAD-14 & $\operatorname{JM1}\left(S_{9} S_{x}\right) \times \operatorname{Mark}\left(S_{3} S_{x}\right)$ & $S_{3} S_{9}$ \\
\hline 13 & KAD-17 & $\operatorname{JM1}\left(S_{9} S_{x}\right) \times \operatorname{Mark}\left(S_{3} S_{x}\right)$ & $S_{3} S_{9}$ \\
\hline 14 & KAD-19 & $\operatorname{JM1}\left(S_{9} S_{x}\right) \times \operatorname{Mark}\left(S_{3} S_{x}\right)$ & $S_{3} S_{9}$ \\
\hline 15 & KAD-20 & $\operatorname{JM7}\left(S_{9} S_{x}\right) \times \operatorname{Mark}\left(S_{3} S_{x}\right)$ & $S_{3} S_{9}$ \\
\hline 16 & JM1 & Malus prunifolia $\times \operatorname{M.9}\left(S_{3} S_{9}\right)$ & $S_{9} S_{x}{ }^{\S}$ \\
\hline 17 & JM7 & Malus prunifolia $\times$ M.9 $\left(S_{3} S_{9}\right)$ & $S_{9} S_{x}{ }^{\S}$ \\
\hline 18 & Mark & M.9 $\left(S_{3} S_{9}\right) \times$ Unknown $^{\neq}$ & $S_{3} S_{x}{ }^{\mathbb{S}}$ \\
\hline 19 & "Jawrasi Golden" & Unknown $^{9} \times$ Unknown $^{\neq}$ & $S_{28} S_{x}{ }^{\mathfrak{S}}$ \\
\hline 20 & “Kado Seb” & Unknown $^{9} \times$ Unknown $^{\neq}$ & $S_{28} S_{x}^{\circledR}$ \\
\hline 21 & "Mahali" & Unknown $^{9} \times$ Unknown $^{\neq}$ & $S_{5} S_{28}$ \\
\hline 22 & "Nazak Badan" & Unknown $^{9} \times$ Unknown $^{\neq}$ & $S_{2} S_{9}$ \\
\hline 23 & "Parachinari" & Unknown $^{9} \times$ Unknown $^{\neq}$ & $S_{x} S_{y}{ }^{\S}$ \\
\hline 24 & "Red Devil" & "Discovery" $\left(S_{10} S_{24}\right) \times$ "Kent" $\left(S_{3} S_{9}\right)$ & $S_{2} S_{24}$ \\
\hline 25 & "Saturn" & "Jonathan" $\left(S_{7} S_{9}\right) \times$ "Golden Delicious" $\left(S_{2} S_{3}\right)$ & $S_{2} S_{7}$ \\
\hline 26 & "Swati" & Unknown ${ }^{9} \times$ Unknown $^{\neq}$ & $S_{3} S_{28}$ \\
\hline 27 & "Tur Kulu" & Unknown $^{9} \times$ Unknown $^{\neq}$ & $S_{2} S_{28}$ \\
\hline
\end{tabular}

${ }^{+}$Incorrect parentage indicated by this work is in bold.

${ }^{*}$ Unknown: pollen parent is unknown.

${ }^{\natural} S_{x}, S_{y} \neq S_{1}, S_{2}, S_{3}, S_{5}, S_{7}, S_{9}, S_{10}, S_{20}, S_{24}, S_{28}$.

'Unknown: ovule parent is unknown.

numbers 4 and 10) might be a sport of "Starking Delicious" $\left(S_{9} S_{28}\right)$ and "Shinano Gold" $\left(S_{1} S_{3}\right)$, respectively, judging from their $S$-genotypes. The reputed paternal parent "Tsugaru" for "Oirase" and an unknown pollen parent for K-24 seemed to be unrelated to their production. The paternal parents of "Suwakko" (Table 1, number 5) are unknown. "American Summer Pearmain" $\left(S_{1} S_{20}\right)$ or "Indo" $\left(S_{7} S_{20}\right)$ or "Kitanosachi" $\left(S_{7} S_{20}\right)$ might be used as a paternal parent of "Suwakko" $\left(S_{3} S_{20}\right)$, given its $S$-RNase genotype and resembling its branch characteristics to "Indo" (Figure 1). In the case of K-23 (Table 1, number 9), either its maternal or its paternal parents were wrong. Since the $S$-RNase genotype of K-25 (Table 1, number 11) was identified as $S_{9} S_{x}$, its maternal parent "Shinano Gold" $\left(S_{1} S_{3}\right)$ might have been wrongly identified. One unknown $S$-RNase allele was present in three (JM1, JM7, and Mark [Table 1, numbers 16-18]) out of seven rootstocks in Japan.

Within the six original Afghan cultivars, "Nazak Badan," "Swati," and "Tur Kulu" (Table 1, numbers 22, 26, and 27) were determined as $S_{2} S_{9}, S_{3} S_{28}$, and $S_{2} S_{28}$, respectively. We also identified S-genotypes of rootstock "Mahali" (Table 1, number 21) as $S_{5} S_{28}$, but one or two unknown $S$-RNase alleles were present in "Jawrasi Golden" $\left(S_{28} S_{x}\right)$, "Kado Seb" $\left(S_{28} S_{x}\right)$, and "Parachinari" $\left(S_{x} S_{y}\right)$ (Table 1, numbers 19, 20, and $23)$. This is the first case to analyze $S$-genotypes of Afghan cultivars.

3.2. Database of S-RNase Allele Genotypes and the Search System for Suitable Apple Cultivar Combination Using the Pashto Language. We previously established a search system for apple cultivar combination, written in English on the homepage (http://www.agr.nagoya-u.ac.jp/ hort/apple/) [23]. In this study, we have developed a Pashto language version of the search system homepage for apple growers in Afghanistan. At first all names of cultivars and their parents in the database were translated from English to the Pashto language. Then, we changed the search system homepage to a Pashto language version. As the writing of the Pashto language reads from right to left, the new homepage looks like an opposite of the English version (Figure 2). 


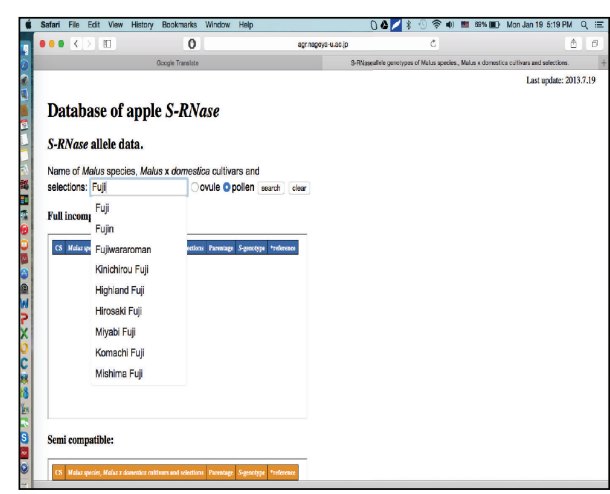

(a)

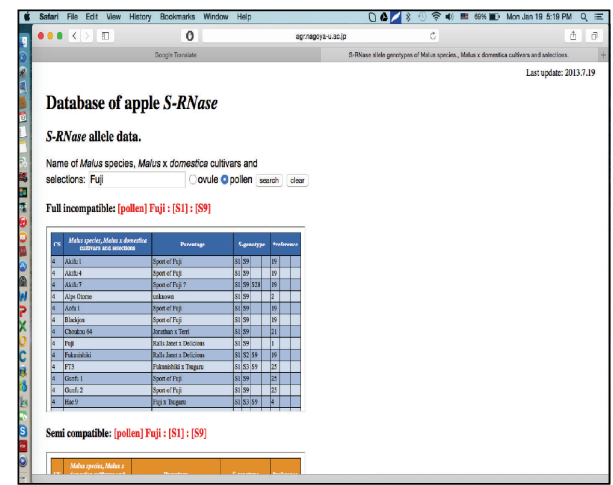

(c)

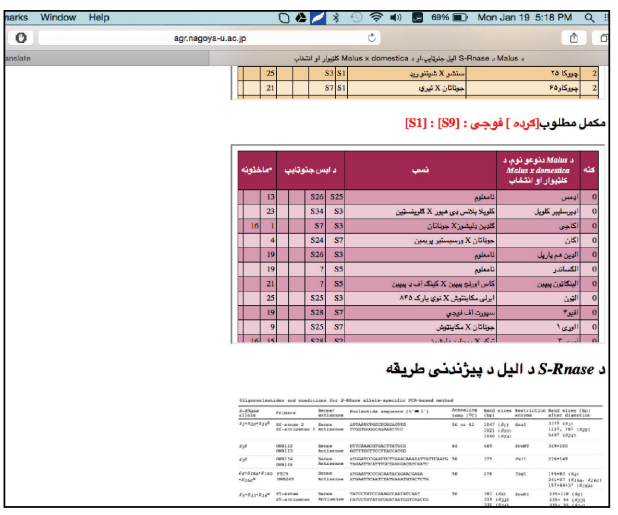

(e)

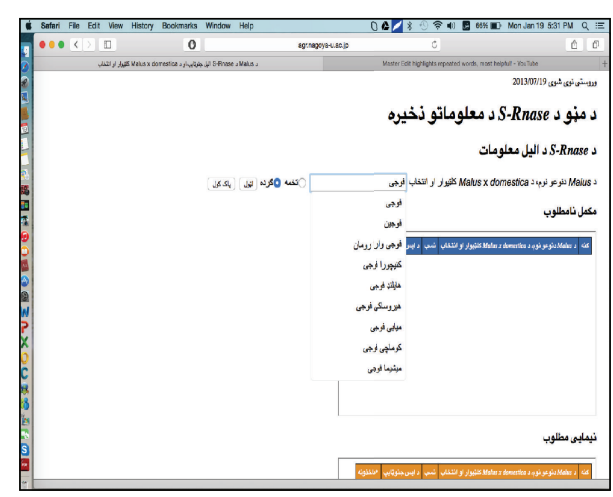

(b)

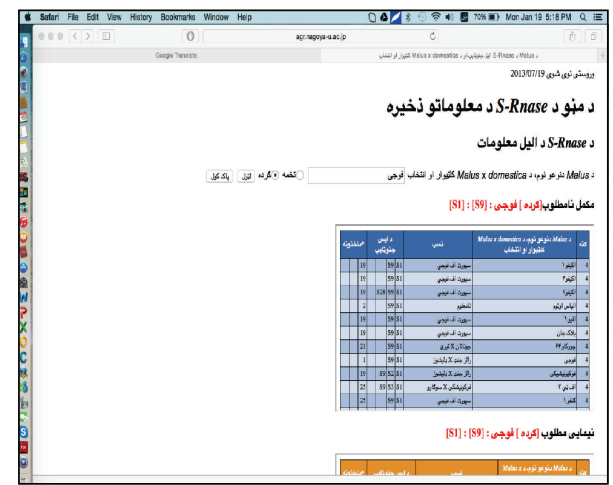

(d)

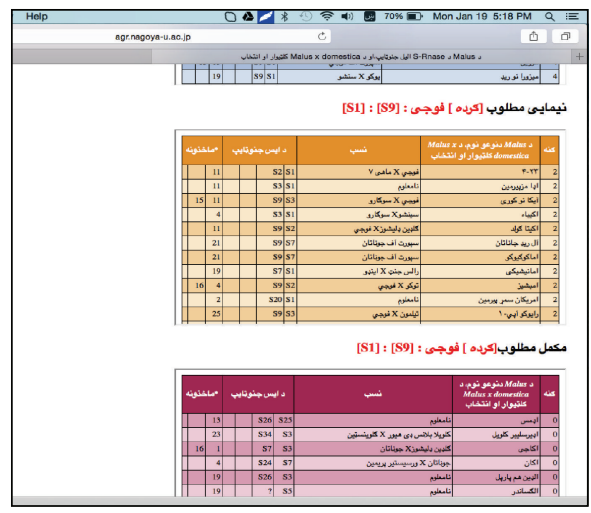

(f)

Figure 2: Pashto language version of representative screenshots of the search system. "Fuji" was selected for searching cultivars on the English version (a) and Pashto version (b). Search results: cultivars incompatible with "Fuji" on the English version (c) and Pashto version (d), cultivars semicompatible with "Fuji" on the Pashto version (e), and cultivars fully compatible with "Fuji" on the Pashto version (f).

All apple growers in Afghanistan can access the homepage at the URL (http://www.agr.nagoya-u.ac.jp/ hort/apple/ps/). In the homepage of this database, there is a box called the search box. When you write the first letter of a cultivar name in the search box, a list of similar cultivar names will appear from which you can select the target cultivar easily (Figures 2(a) and 2(b)). Afterward, before clicking the search button, you must decide if the cultivar is used as an ovule parent or pollen parent. Then click the search button. Actually, the search system of $S$-genotype database is developed for suitable combinations of apple cultivars. The search system of $S$-genotype database indicates three different types of combinations between apple cultivars: full-incompatibility, semicompatibility, and full-compatibility. Therefore, you will find three different open windows reflecting the 3 compatibilities mentioned above (Figures 2(c)-2(f)).

\section{Conclusions}

We have investigated 27 S-RNase genotypes of apple cultivars and lineages including the nine most useful Afghanistan apple cultivars. We developed a Pashto language version of 
the $S$-genotypes database of apple cultivars, along with a convenient search system for cultivar combination showing three different types of compatibilities, that is, full-compatibility, semicompatibility, and full-incompatibility. The translated Pashto version of the search system will enable apple growers in Afghanistan to select suitable and compatible apple cultivars for successful combination in an orchard to ensure stable fruit production and breeding.

\section{Conflict of Interests}

The authors declare that there is no conflict of interests regarding the publication of this paper.

\section{Acknowledgments}

The authors are indebted to Mr. T. Okawa for his technical advice in developing a DNA database with a search capability and to Mr. T. Takano and Mr. T. Asakawa for supplying the samples for new apple cultivars and lineages. This research was carried out under the Project for the Promotion and Enhancement of the Afghan Capacity for Effective Development (PEACE).

\section{References}

[1] J. Safi and D. Bunnel, "Afghanistan's vibrant apple market," Global Agricultural Information Network, USDA Foreign Agricultural Service, 2013, http:/gain.fas.usda.gov/Recent\%20GAIN \%20Publications/Afghanistan's\%20Vibrant\%20Apple\%20Market_Kabul_Afghanistan_11-18-2013.pdf.

[2] D. de Nettancourt, Incompatibility in Angiosperms, Monographs on Theoretical and Applied Genetics, Springer, Heidelberg, Germany, 1977, edited by: R. Frankel, G. A. E. Gal, H. H. Linskens.

[3] F. Kobel, P. Steinegger, and J. Anliker, "Weitere untersuchungen über die befruchtungsverhältnisse der apfel- und birnsorten," in Landwirtschaftliches Jahrbuch der Schweiz, vol. 53, pp. 160-191, 1939.

[4] W. Broothaerts, G. A. Janssens, P. Proost, and W. F. Broekaert, "cDNA cloning and molecular analysis of two selfincompatibility alleles from apple," Plant Molecular Biology, vol. 27, no. 3, pp. 499-511, 1995.

[5] P. De Franceschi, L. Dondini, and J. Sanzol, "Molecular bases and evolutionary dynamics of self-incompatibility in the Pyrinae (Rosaceae)," Journal of Experimental Botany, vol. 63, no. 11, pp. 4015-4032, 2012.

[6] R. S. G. Dreesen, B. T. M. Vanholme, K. Luyten et al., "Analysis of Malus S-RNase gene diversity based on a comparative study of old and modern apple cultivars and European wild apple," Molecular Breeding, vol. 26, no. 4, pp. 693-709, 2010.

[7] G. A. Janssens, I. J. Goderis, W. F. Broekaert, and W. Broothaerts, "A molecular method for $S$-allele identification in apple based on allele-specific PCR," Theoretical and Applied Genetics, vol. 91, no. 4, pp. 691-698, 1995.

[8] H. Sassa, T. Nishio, Y. Kowyama, H. Hirano, T. Koba, and H. Ikehashi, "Self-incompatibility $(S)$ alleles of the Rosaceae encode members of a distinct class of the $\mathrm{T}_{2} / \mathrm{S}$ ribonuclease superfamily," Molecular and General Genetics, vol. 250, no. 5, pp. 547-557, 1996.
[9] K. Kitahara and S. Matsumoto, "Sequence of the S10 cDNA from 'McIntosh' apple and a PCR-digestion identification method," HortScience, vol. 37, no. 1, pp. 187-190, 2002.

[10] S. Matsumoto, K. Okada, A. Kojima, K. Shiratake, and K. Abe, "S-RNase genotypes of apple (Malus domestica Borkh.) including new cultivars, lineages, and triploid progenies," The Journal of Horticultural Science and Biotechnology, vol. 86, no. 6, pp. 654-660, 2011.

[11] K. Kitahara, H. Fukui, J. Soejima, and S. Matsumoto, "Cloning and sequencing of a new S-gene 'Sg-RNase' (accession no. AB019184) from Malus $\times$ domestica Borkh. 'Indo' (PGR99-046)," Plant Physiology, vol. 119, p. 1567, 1999.

[12] J. Morita, K. Abe, and S. Matsumoto, "S-RNase genotypes of apple cultivars grown in Japan and development of a PCR-RFLP method to identify the $S_{6}$ - and $S_{21}$-RNase alleles," Journal of Horticultural Science \& Biotechnology, vol. 84, no. 1, pp. 29-34, 2009.

[13] K. Kitahara and S. Matsumoto, "Cloning of the $S_{25} \mathrm{cDNA}$ from 'McIntosh' apple and an $S_{25}$-allele identification method," Journal of Horticultural Science and Biotechnology, vol. 77, no. 6, pp. 724-728, 2002.

[14] S. Matsumoto, T. Eguchi, H. Bessho, and K. Abe, "Determination and confirmation of $S$-RNase genotypes of apple pollinators and cultivars," Journal of Horticultural Science \& Biotechnology, vol. 82, no. 2, pp. 323-329, 2007.

[15] Apple Manual-ROP, Afgan Agriculture, 2008, http://afghanag .ucdavis.edu/a_horticulture/fruits-trees/apples/reports-apple/.

[16] Afghanistan Horticulture, Afghanistan Natural Horticulture Department Organization, http://afghanistanhorticulture.org/ pages/Germplasm.aspx.

[17] M. R. Thomas, S. Matsumoto, P. Cain, and N. S. Scott, "Repetitive DNA of grapevine: classes present and sequences suitable for cultivar identification," Theoretical and Applied Genetics, vol. 86, no. 2-3, pp. 173-180, 1993.

[18] W. Broothaerts, G. A. Janssens, P. Proost, and W. F. Broekaert, "cDNA cloning and molecular analysis of two selfincompatibility alleles from apple," Plant Molecular Biology, vol. 27, no. 3, pp. 499-511, 1995.

[19] K. Kitahara, J. Soejima, H. Komatsu, H. Fukui, and S. Matsumoto, "Complete sequences of the $S$-genes, $S d$ - and Sh-RNase cDNA in apple," HortScience, vol. 35, pp. 712-715, 2000.

[20] S. Matsumoto, S. Komori, K. Kitahara, S. Imazu, and J. Soejima, "S-genotypes of 15 apple cultivars and self-compatibility of 'Megumi”,' Journal of the Japanese Society for Horticultural Science, vol. 68, no. 2, pp. 236-241, 1999.

[21] S. Matsumoto, K. Kitahara, S. Komori, and J. Soejima, "A new Sallele in apple, 'Sg', and its similarity to the 'Sf' allele from 'Fuji,' HortScience, vol. 34, no. 4, pp. 708-710, 1999.

[22] S. Matsumoto and K. Kitahara, "Discovery of a new selfincompatibility allele in apple," HortScience, vol. 35, no. 7, pp. 1329-1332, 2000.

[23] S. Matsumoto, "Apple pollination biology for stable and novel fruit production: search system for apple cultivar combination showing incompatibility, semicompatibility, and fullcompatibility based on the S-RNase allele database," International Journal of Agronomy, vol. 2014, Article ID 138271, 9 pages, 2014. 


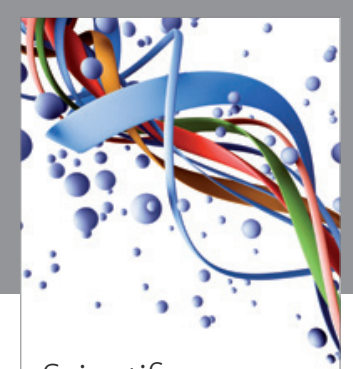

Scientifica
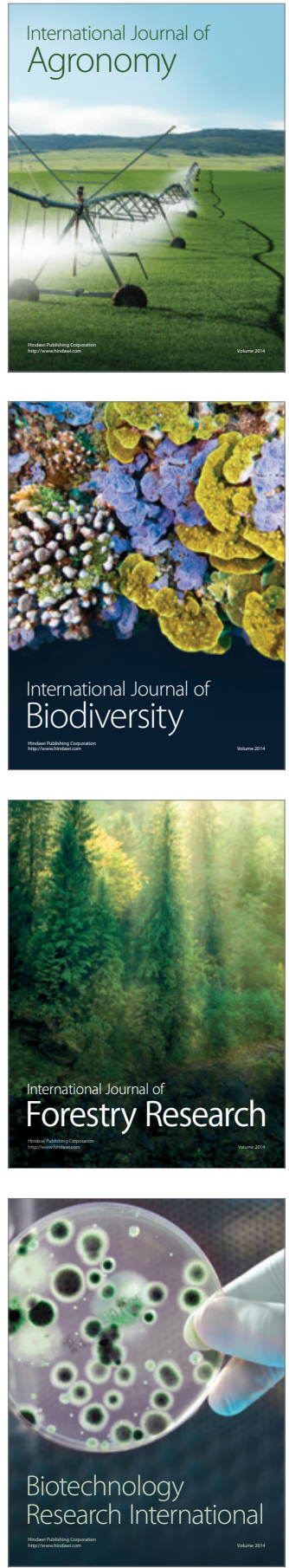
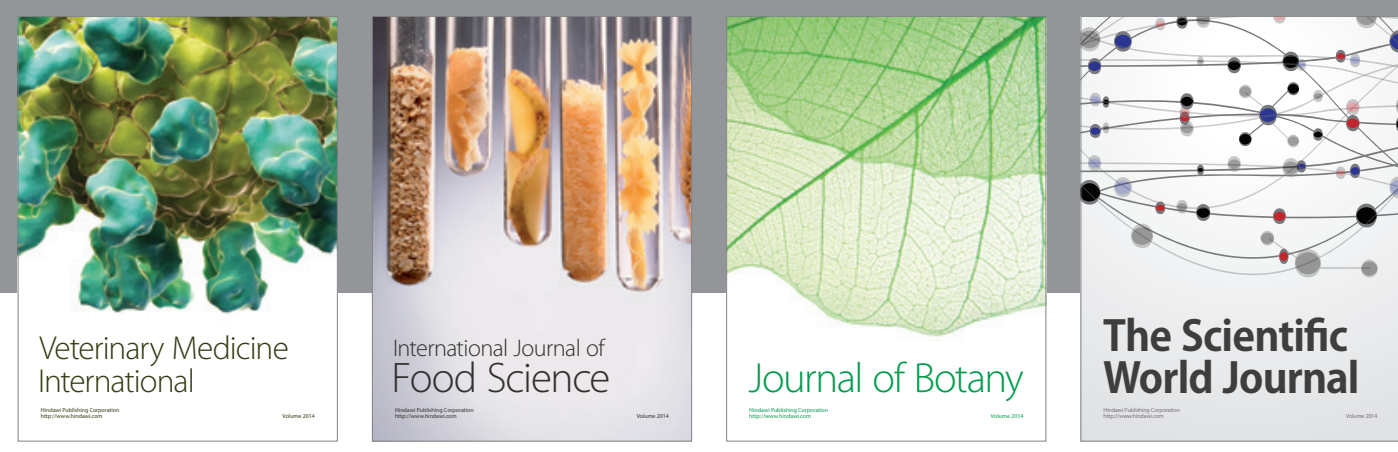

The Scientific

\section{World Journal}

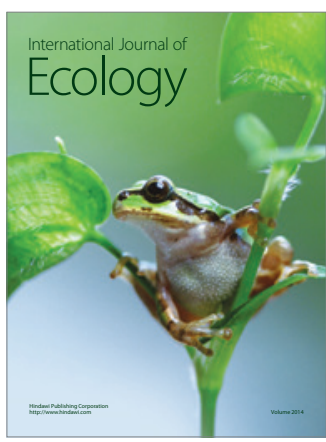

\section{Hindawi}

Submit your manuscripts at

http://www.hindawi.com
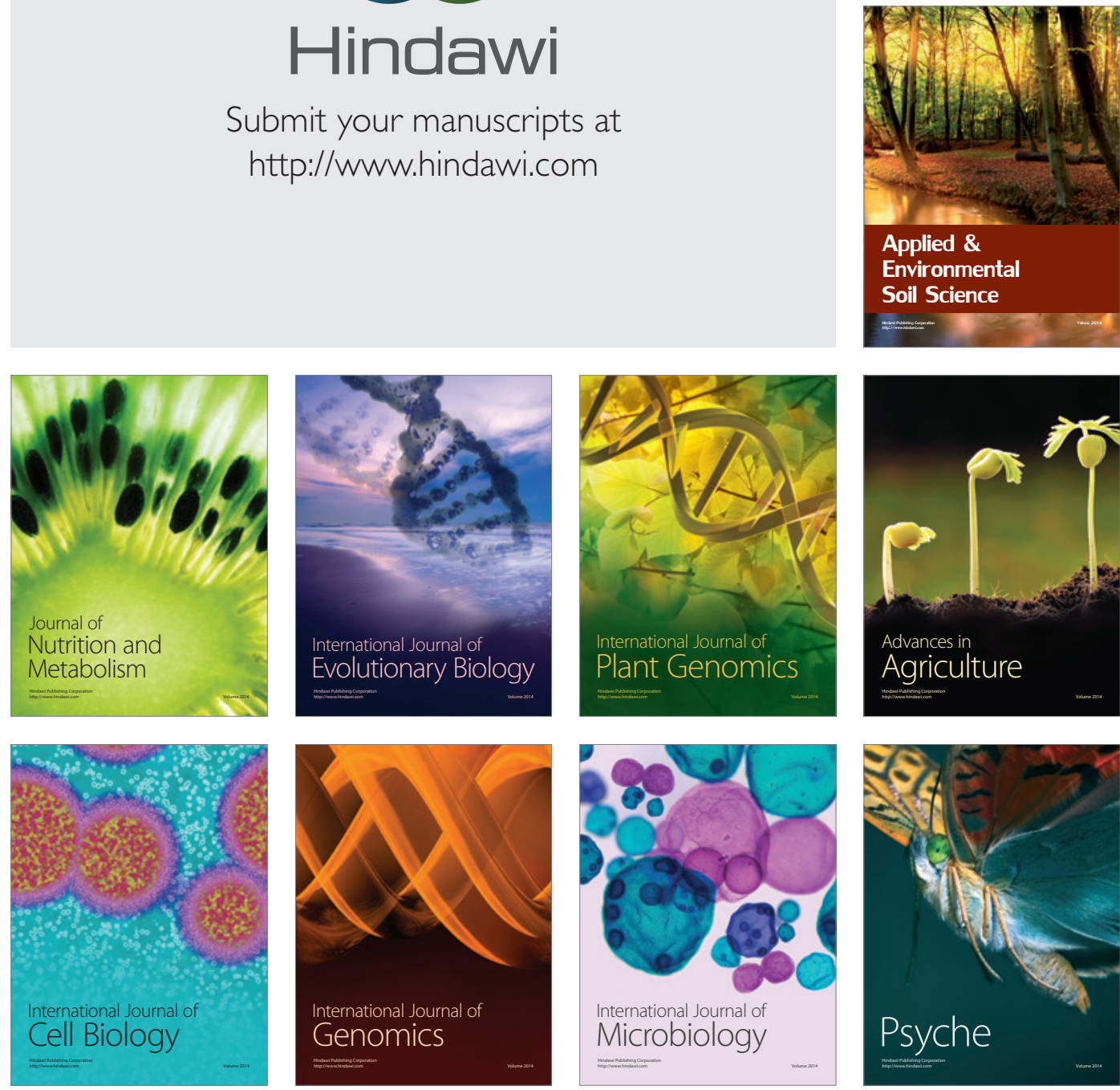
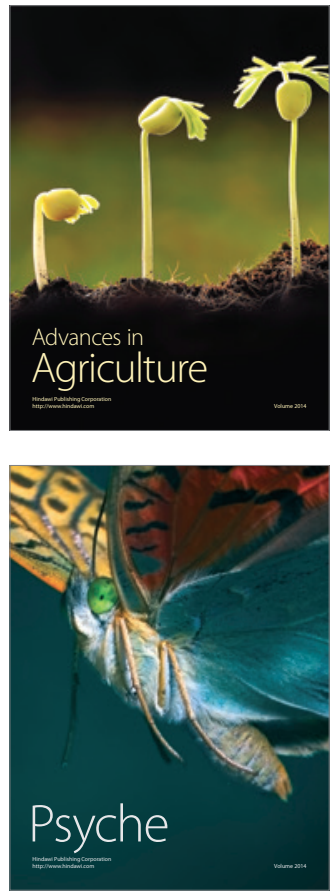